\title{
AFRICAN HUMAN RIGHTS LAW JOURNAL
}

To cite: AM Ibrahim 'LGBT rights in Africa and the discursive role of international human rights law' (2015) 15 African Human Rights Law Journal 263-281

http://dx.doi.org/10.17159/1996-2096/2015/v15n2a2

\section{LGBT rights in Africa and the discursive role of international human rights law}

\author{
Abadir M Ibrahim* \\ Adjunct Professor, St Thomas University School of Law, Miami, United States \\ of America
}

\begin{abstract}
Summary
Much of Africa seems to be riding on a homophobic wave that is being billed as an African resistance to Western attempts to force homosexuality on Africa. However, this Africanisation of homophobia is based on false premises. Pre-colonial Africa entertained a diverse set of ways in which non-heterosexuality and non-heteronormativity were expressed and it was colonialism that introduced the now widespread religious and legal norms that policed sexuality and gender. The current wave of homophobia is also based on Western anti-LGBT rights discourses and in some part is sponsored by Western/American evangelical groups. The article argues that the imposition of an African label on colonial and neo-colonial products needs to be challenged without, however, effectively replacing it with an equally Western construct. The article advocates a grassroots and ground-up approach wherein international law on LGBT rights is used for its discursive value at the societal, national and regional levels. As part of this approach, it is argued that activists should temporarily refrain from bringing LGBT cases to the African Commission on Human and Peoples' Rights since a detrimental decision, which currently is extremely likely, can cause serious and long-term problems.
\end{abstract}

Key words: LGBT rights; sexual orientation; African Commission on Human and Peoples' Rights; discrimination; homophobia 


\section{Introduction}

I cannot but be as God has made me. And so I spoke against the injustices of apartheid, about racism, where people were penalised for something about which they could do nothing, their ethnicity. I, therefore, could not keep quiet when people were hounded for something they did not choose, their sexual orientation.

Archbishop Desmond Tutu ${ }^{1}$

In February 2014, Uganda's notorious Anti-Homosexuality Act was signed into law, bringing to a climax a five-year saga apparently sparked and sponsored by American evangelical groups. Less than half a year later, the country's Supreme Court struck down the law on technical grounds, allegedly due to pressure put on President Museveni by Western governments. ${ }^{2}$ While many have analysed the role of Western evangelical organisations in lobbying for this law, ${ }^{3}$ the situation on the continent is more complex and wider than Uganda. Following a wave of successful campaigns for gay marriage in Europe and America, many African governments have been taking or talking about measures in the opposite direction. Although positive developments have taken place, such as Mozambique's phasing out of colonial Portuguese laws penalising homosexual acts in July 2015, the trend indicates that before the situation of sexual and gender minorities improves in Africa, it could get much worse.

In recognition of the situation of $\mathrm{LGBT}^{4}$ rights organisations, human rights experts rightly warn that now is not a good time to utilise judicial mechanisms, including the African Commission on Human and Peoples' Rights (African Commission), to ensure the protection of LGBT rights. There is currently the likelihood that judicial organs will set dangerous precedents that have the effect of thwarting the progressive development of LGBT rights. The article argues that international law is valuable in the promotion of human rights, even if it is not used in courts. It suggests specific strategies on how international human rights regimes can be mobilised to advance LGBT rights as part of a larger advocacy strategy. It also argues that activists working to protect LGBT rights should, unlike the homophobic campaign, look to and encourage African organisations and discourses rather than importing their campaign wholesale.

1 D Tutu 'International Gay and Lesbian Human Rights Commission 2008', Grace Cathedral, San Francisco, 8 April 2008, http://www.youtube.com/watch? V=ONVgf_RHrkk (accessed 30 July 2015).

2 BBC News 'Uganda court annuls anti-homosexuality law' 1 August 2014 http:// www.bbc.com/news/world-africa-28605400 (accessed 30 July 2015).

3 See $n 30$ below.

4 LGBT is used in this article as a short form for lesbian, gay, bisexual and transgender. Whereas the homophobic laws that the article deals with are typically meant to outlaw and repress non-heterosexual sexual orientation, they will in practice produce consequences adversely affecting individuals with nonconforming gender identities as well. It is for that reason that the article elects to merge both issues and to take a broader look. 


\section{Background: An African debate that is also not African}

Among the international actors discussing, or rather arguing about, the rights of sexual and gender minorities, many African nations have come to the fore in opposing the notion that LGBT rights should be protected legally. In the United Nations (UN) General Assembly and Human Rights Council, for example, a group of African nations have forged an alliance with the Organisation of Islamic Conference in opposing initiatives to afford greater protection to LGBT rights. ${ }^{5}$ Additionally, 36 African countries criminalise sodomy and this list includes those that impose life imprisonment and the death sentence. ${ }^{6}$ Nineteen African nations, however, have never had sodomy laws or have decriminalised homosexuality. ${ }^{7}$ South Africa, which legally recognises gay marriage, has supported LGBT rights in international fora, albeit without speaking out against the laws and practices of its African neighbours. ${ }^{8}$ Although this statistic already draws a gloomy picture, there are now movements in many countries that create momentum to make things worse.

Africa presents a multi-layered paradox, as the pro- and anti-LGBT rights movements in the region are directly and indirectly connected to sexual/gender minority politics in the west. First, contemporary laws in most of Africa were imposed on the continent by colonial powers, whether of the Christian or Islamic variant, and there is some indication that homophobia might have been the exception and very mild in pre-colonial Africa. ${ }^{9}$ Therefore, there is something deceitful about the anti-LGBT rights campaign in how it legitimises a colonial imposition as something that is essentially African. However, at the same time, many colonial practices have been so entrenched that they are no longer dismissed as alien.

5 Generally, Human Rights Council 'Human Rights Council Panel on Ending Violence and Discrimination against Individuals Based on their Sexual Orientation and Gender Identity' Geneva, Switzerland, 7 March 2012.

6 LP Itaborahy \& J Zhu 'State-sponsored homophobia: A world survey of laws: Criminalisation, protection and recognition of same-sex love' International Lesbian, Gay, Bisexual, Trans- and Intersex Association, May 2003; also see J Jolly 'Africa's lesbians demand change' BBC News 27 February 2008.

7 Countries that do not criminalise homosexual acts are Benin, Burkina Faso, Cape Verde, Central African Republic, Congo, Chad, Côte d'Ivoire, Democratic Republic of Congo, Djibouti, Equatorial Guinea, Gabon, Guinea-Bissau, Lesotho, Madagascar, Mali, Mozambique, Niger, Rwanda and South Africa. See International Lesbian, Gay, Bisexual, Trans- and Intersex Association Statesponsored homophobia: A world survey of laws: Criminalisation, protection and recognition of same-sex love (2013) 22.

8 J Dougherty 'UN Council passes gay rights resolution' CNN 17 June 2011; JL Feder 'South Africa, which once led on promoting LGBT rights abroad, could become a roadblock' BuzzFeed News 18 September 2014 http://www.buzzfeed.com/les terfeder/lgbt-rights-resolution-passes-united-nations-human-rights-co\#.iivd81Prm (accessed 30 July 2015).

9 See nn 18-22 below. 
Second, while there is contemporaneously no shortage of homegrown homophobia, the recent push against LGBT rights is ideologically and financially supported by conservative Christian groups from the west. The recent alien torts claim against Scott Lively ${ }^{10}$ for his role in lobbying for the Ugandan draft 'kill the gays' legislation and the complicity of American evangelical organisations in sponsoring this bill are only two reminders of the transnational nature of the anti-LGBT rights movement. ${ }^{11}$ At the same time, the LGBT rights movement, itself, is also heavily influenced by the narratives, styles and colours of Western LGBT rights activism, in addition to being backed by Western organisations. Although acceded to in this article for its salience in international human rights discourse and to some extent the discourse of the African Commission itself, the 'LGBT' lexicon is evidence of the predominance of Western discourses on sexuality which may not reflect the experiences and identities of Africans with non-conforming sexualities or genders.

Given the role of European colonial legislation, Christianity, Islam and Western/American conservatism, and global LGBT rights activists and organisations, it appears as if the debate on LGBT rights in Africa is far from being solely African. It is a universal debate that is simultaneously taking place in other parts of the world, sometimes with the same actors involved in the West and Africa. To the extent that the homophobic discourse is transcontinental, LGBT rights activism is becoming inevitably multi-local as well. As a cumulative result of the non-African discourses colouring both homophobic and pro-rights discourses, one may rightly observe that Africans increasingly are finding themselves joining in a Western debate that is rapidly becoming globalised. By the mere fact that Africans on all sides are joining the debate, they are also globalising and privileging the hitherto alien discourses on the topic.

\section{LGBT rights in public discourse: The war over signification}

Despite the Western roots of the contemporary homophobic wave that is sweeping Africa, one of the major arguments that are being voiced against the protection of LGBT rights is that homosexuality is 'un-African'. ${ }^{12}$ By characterising homophobia as part of African culture, the 'un-African' narrative claims that the difference really is

10 Sexual Minorities Uganda v Scott Lively CA 12-cv-30051-Map 14 August 2013; also see M Bennett-Smith 'Scott Lively, "Kill the gays" Bill supporter, says "Right to sodomy" is destroying human rights' The Huffington Post 23 January 2013.

11 See $n 30$ below.

12 Generally see SK Mazzochi 'The great debate: Lessons to be learned from an international comparative analysis on same-sex marriage' (2011) 16 Roger Williams University Law Review 600-602; LC Backer 'Emasculated men, effeminate law in the United States, Zimbabwe and Malaysia' (2005) 17 Yale Journal of Law and Feminism 29-32. 
one of culture and that there is no reason why Africa should abandon its culture in favour of the West's. Repeated enough times, underlined with religious zeal and the threat of supernatural damnation, this narrative slowly has resulted in widespread hatred. In Uganda, Nigeria, Kenya and Tanzania such narratives have resulted in a vigilante-type violence and the persecution of homosexual individuals and human rights defenders.

This notion of cultural relativism has been abused by past African political elites to claim that Africans do not have rights protecting them against mass murder and torture. ${ }^{13}$ Mobutu Sese Seko, for example, justified his position as lifelong corrupt dictator in reference to African culture. 'Democracy is not for Africa', he said. 'There was only one African chief. ${ }^{14}$ As if the deployment of European/colonial stereotypes $^{15}$ about Africa's pre-colonial political experience was not enough, Mobutu also borrowed from colonial predecessors the idea of imposing forced labour on the population, resulting in the bondage of rural populations. Paradoxically, while African dictators imposed forced labour because such was supposedly demanded by African culture, the colonial stereotype that preceded them was that labour needed to be imposed on Africans because such practice had no precedent in pre-colonial African culture. ${ }^{16}$

The same notion is now deployed against sexual minorities, paving the way for discrimination and the criminalisation of sexual orientation and identity. African culture, essentialised and stripped of its diversity, is presented as homogenously heterosexual and inherently homophobic. Typically, the claim is that Africans 'are unique people whose culture, morality and heritage totally abhor homosexual and lesbian practices and indeed any other form of unnatural sexual acts'. 17 Such a view has been promoted despite the fact that anthropological and historical evidence reveals that the claim is unfounded. The demystification of homophobic pseudo-history and

13 R Burke Decolonisation and the evolution of international human rights (2010) ch 5.

14 Wall Street Journal 14 October 1985.

15 In many parts of Africa, the institution of the chief was invented by colonial administrators and departments because that is how they expected Africans to organise, even though the African experience was much more diverse. Since the deployment of authoritarian chiefs made administration and the collection of revenues, the administrators were probably motivated primarily by convenience rather than mere essentialism. See C Lentz Ethnicity and the making of history in Northern Ghana (2006) 33-71; also see W Easterly The white man's burden: Why the west's efforts to aid the rest have done so much ill and so little good (2006) 274278.

16 TM Callaghy 'State-subject communication in Zaire: Domination and the concept of domain consensus' (1980) 18 Journal of Modern African Studies 490-492; for an interesting account of a colonial account, see RL Doty Imperial encounters (1996) ch 3.

17 E Mittelstaedt 'Safeguarding the rights of sexual minorities: The incremental and legal approaches to enforcing international human rights obligations' (2008) 9 Chicago Journal of International Law 368-369. 
the detachment of homophobia from 'African-ness' are, thus, a necessary first step in the promotion of LGBT rights.

From the outset it should be made clear that homosexuality, tolerance or, for that matter, homophobia are not alien to precolonial, colonial or post-colonial Africa. ${ }^{18}$ In pre-colonial and colonial times, not only was there a more diverse understanding of sex, gender and family than the Western Judeo-Christian one, ${ }^{19}$ but the treatment of sexual and gender minorities within African cultures could have varied from discouraging public discussion of homosexual desires and acts to complete tolerance of LGBT minorities, including the institutionalisation of some forms of same-sex relationships. ${ }^{20}$

There is evidence showing not only that same-sex intimacy was tolerated in ancient Egypt, but that at certain periods same-sex relationships were legally recognised. ${ }^{21}$ Among the Azande, in precolonial Sudan, male same-sex marriage was legally recognised where dowry was paid to boy-wives and damages were awarded for infidelity. ${ }^{22}$ The Meru people of Kenya, the Bantu of Angola and the Zulu of South Africa tolerated transgender men and allowed them to marry other men, while gay prostitution is reported among the Hausa of Nigeria. 23 Effeminate males among the Langi of Uganda were allowed to marry men. ${ }^{24}$ In Zimbabwe, LGBT affection, while being tolerated, was not publicly displayed or discussed, in the same way

18 See, generally, BS Pincheon 'An ethnography of silences: Race, (homo)sexualities, and a discourse of Africa' (2000) 43 African Studies Review 39; S Murray \& W Roscoe (eds) Boy wives and female husbands: Studies in African homosexualities (1998); RC Bleys The geography of perversion: Male-to-male sexual behaviour outside the west and the ethnographic imagination, 1750-1918 (1995); DP Amory "'Homosexuality" in Africa: Issues and debates' (1997) 25 A Journal of Opinion 5; D Constantine-Simms (ed) The greatest taboo: Homosexuality in black communities (2000) 132; WN Eskridge Jr 'A history of same-sex marriage' (1993) 79 Virginia Law Review 1419.

19 Eg, see the debate on sex and women-to-woman marriages in Kenya in CW Kitetu \& AN Kioko 'Issues of language and gender in marriage as practised by the Kamba in Kenya' in LL Atanga et al (eds) Gender and language in sub-Saharan Africa: Tradition, struggle and change (2013); I Amadiume Male daughters, female husbands: Gender and sex in an African society (1987).

20 See Eskridge (n 18 above) 1437-1441 1458-1462; MJ Herskovits 'A note on "woman marriage" in Dahomey' (1937) 10 Africa 335; RS Oboler 'Is the female husband a man? Woman/woman marriage among the Nandi of Kenya' (1980) 19 Ethnology 69.

21 Eskridge (n 18 above) 1437-1441; also see generally TA Dowson 'Archaeologists, feminists, and queers: Sexual politics in the construction of the past' in PL Geller \& MK Stockett (eds) Feminist anthropology: Past, present, and future (2006) 96-98. The most documented type of institutionalised or ritualised homosexual expression, however, related to the expression of aggression against other men, especially in the context of war. Generally, see T Murphy (ed) Reader's guide to lesbian and gay studies (2000) 198-199.

22 EE Evans-Pritchard 'Sexual inversion among the Azande' (1970) 72 American Anthropologist 1428-1434.

23 DF Greenberg The construction of homosexuality (1988) 60-61.

24 S Tamale 'Homosexuality is not un-African' Al Jazeera 26 April 2014 http:// america.aljazeera.com/opinions/2014/4/homosexuality-africamuseveniugandanig eriaethiopia.html (accessed 30 July 2015). 
that heterosexual affection was tabooed. ${ }^{25}$ The Amhara in Ethiopia, unlike their Western Christian counterparts, tolerated sexual minorities, whom they considered 'God's mistakes' rather than criminals who needed to be punished. ${ }^{26}$ It was with the imposition of colonialism and white rule that homosexuality was criminalised and harshly punished in sub-Saharan Africa, including with both corporal and capital punishment. ${ }^{27}$

Murray and Roscoe, in the most comprehensive book on the subject, point out that ${ }^{28}$

[t]he colonialists did not introduce homosexuality to Africa but rather intolerance of it - and systems of surveillance and regulation for suppressing it ... these systems were not successful as long as the reaction of the colonised was simply to hide or deny such practices. Only when native people began to forget that same-sex patterns were ever a part of their culture did homosexuality become truly stigmatised.

While homophobia had been entrenched in African ethical and legal systems by the time colonialism ended, much of the homophobic rhetoric that is currently on the rise is once again taken from Western homophobic campaigns. Major players, for example, are either Western educated conservatives ${ }^{29}$ or are directly funded or supported by Western (specifically American) homophobia campaigners. ${ }^{30}$

Although this study is not an empirical one, and therefore should not be perceived to be making statistical claims, it looks as though a strong hypothesis can be made regarding the role of conservative or fundamentalist religion in promoting homophobia in Africa. In a comparative study of Europe and North America, Kollman concluded that religiosity and confessional heritage play a significant role in the non-acceptance of LGBT rights. ${ }^{31}$ A case in point is the recent Irish constitutional referendum to allow same-sex marriage. During this process, religious groups made up a significant segment of the 'No'

25 Eg see M Epprecht "The "unsaying" of indigenous homosexualities in Zimbabwe: Mapping a blindspot in an African masculinity' (1998) 24 Journal of South African Studies 633-638.

26 Murray \& Roscoe (n 18 above) 22.

27 Epprecht (n 25 above) 645-646; see also generally B Anderson 'The politics of homosexuality in Africa' (2007) 1 Africana 123; A Gupta This alien legacy - The origins of "sodomy" laws in British colonialism (2008).

28 Murray \& Roscoe (n 18 above) xvi.

29 Epprecht (n 25 above) 647.

30 W Besen 'What is the endgame of the anti-gay movement?' Huffington Post 23 May 2013: I Gettleman 'Americans' role seen in Uganda anti-gay push' New York Times 3 January 2010; T McVeigh et al 'Anti-gay bigots plunge Africa into new era of hate crimes' The Guardian 12 December 2009; Z Alsop 'Uganda's antigay Bill: Inspired by the US Time 10 December 2009; D Englander 'Protecting the human rights of LGBTI people in Uganda in the wake of Uganda's "Anti Homosexuality Bill, 2009"' (2011) 25 Emory International Law Review 1270-1273; L Carasik 'Retrogressive anti-gay law in Uganda has ties to the US' AlJazeera 13 January 2014.

31 See K Kollman 'Same-sex unions: The globalisation of an idea' (2007) 51 International Studies Quarterly 347-351. 
lobby and, not surprisingly, these groups are said to have financially benefited from American right-wing Christian support. ${ }^{32}$

In the case of Africa, the same laws, religions and sometimes the same Western religious organisations are contending to shape the narrative on LGBT issues and may be responsible for a new wave of homophobia, discrimination and violence. While it is not suggested that religion takes the sole responsibility for homophobia in Africa, it is clear that it plays a central role that needs to be taken into account. On top of the religious overtone, one notices how the Western especially American conservative - discourse dominates the African homophobic campaign which takes up other conservative issues as well.

In a recent rally against President Obama's visit to Kenya, for example, protestors are seen with familiar slogans such as 'Stand with the family' and 'Protect the family'. Given the fact that same-sex acts are illegal in Kenya and gay marriage is not at issue, the adoption of anti-gay marriage rhetoric and slogans shows how much inspiration the protest might have derived from Western/American conservatism. Reverberating the American 'Adam and Eve, not Adam and Steve' slogan, participants chanted 'We do not want Obama and Obama; we do not want Michelle and Michelle. We want Obama and Michelle and we want a child! ${ }^{33}$ In the same rally, a member of parliament tapped into more than one American conservative agenda in a speech where he stated: 'We are telling Mr Obama when he comes to Kenya this month and he tries to bring the abortion agenda, the gay agenda, we shall tell him to shut up and go home. ${ }^{\prime 34}$ William Ruto, the Deputy-President of Kenya, who sees homosexuality as 'unchristian' and 'dirty', 35 states that his position is meant 'to defend our faith, and to defend our religion, and to defend our country'. ${ }^{36}$

The insertion of religious claims that are borrowed from the West into Africa suggests that the war over signification is going to take place, not only regarding whether the African subject is by definition and always homophobic, but also regarding whether the divine is bigoted. In addition to a general progressive discussion, LGBT rights advocates may find themselves compelled to utilise religious pro-LGBT rights polemics in order to make religion-based arguments for tolerance and to counter fundamentalist animosity towards minorities.

32 H McDonald 'US Christians "bankrolling" no campaign in Ireland's gay marriage referendum' The Guardian 16 May 2015.

33 A Laing 'Kenyan politicians tell Barack Obama to leave "gay rights" talk at home' The Telegraph 6 July 2015 http://www.telegraph.co.uk/news/worldnews/ barackobama/11721249/Kenyan-politicians-tell-Barack-Obama-to-leave-gay-rights -talk-at-home.html (accessed 30 July 2015).

$34 \mathrm{H}$ Malalo 'MP tells anti-gay rally: Obama should not push gay agenda in Kenya' Reuters 6 July 2015 http://news.yahoo.com/mp-tells-anti-gay-rally-obama-notpush-132438907.html (accessed 30 July 2015).

35 As above.

36 'DP Ruto says Kenya will not tolerate gay practices' 5 July 2015 https://www. youtube.com/watch?v=t-nPRLjbMYU (accessed 30 July 2015). 
The thinking seems to be that in 'Christian Africa', institutions and liberation theologies need not be re-invented as, similar to homophobia, these too can be appropriated from the West and modified for use in African countries. ${ }^{37}$ Given how the firebrand conservative view has succeeded in holding root, it is clear that support of LGBT-affirming or tolerant religious groups and views is long overdue. However, not only may Queer theology be too radical for the ears of many African believers, but the importation of such constructs or churches may rightly be considered a Western imposition akin to the Evangelical homophobia.

On the other hand, however, while moves such as the utilisation of Queer theology by definition do not account for indigenous or African expressions of religion, non-heterosexuality and nonheteronormativity, they may be a necessary evil to counter the homophobic pro-violence religious narrative. A religion-based narrative assumes an audience that is deeply steeped in the Christian faith and, therefore, already conversant in non-African and global religious discourses. However, to the extent that expressions of African homosexualities persist or are in formation within African cultures, activists should be careful not to put these under pressure by inadvertently replacing them with already-privileged Western expressions.

As much as possible, therefore, indigenous expressions and forms of signification should take precedence to prevent LGBT rights activism from becoming yet another expression of cultural hegemony. Not only may LGBT individuals and rights activists have strong local and pan-African affinities and identities that will push them towards resisting a culturally-hegemonic approach, but such an approach can also force individuals to identify in ways that are alien and inappropriate to their own contexts. It is the African LGBT agents who know their subject positions and contexts best and should be supported to craft their own discourses and strategies. The overpoliticisation of LGBT issues, the rigid categorisation of LGBT identities, an over-emphasis on gay marriage, and the deployment of forms of protest and symbols that typify the West may not be in the best interests of the LGBT rights movement in Africa. Local organisations and religious leaders should take the lead in protecting local cultural expressions of sexuality and gender in figuring out the future of LGBT rights in Africa. Additionally, a Western hegemonic approach is bound to illicit a negative reaction from Africans, including human rights activists, who are shaped in part by a disdain for their colonial histories and neo-colonial realities.

A final matter that needs to be noted is the role of religious leaders in either preventing/curtailing or spreading violence against sexual or gender minorities, even where they are in disagreement over the propriety of protecting LGBT rights. Religious institutions are known

37 Eg, see S Hunt (ed) Contemporary Christianity and LGBTI sexualities (2009). 
to have played a significant role in supporting human rights in apartheid South Africa and in almost all post-independence dictatorial contexts and they continue to play this role in many countries. However, given the prominent role being played by religious organisations in the homophobic campaign, religious leaders need to be reminded that religion can play a distressing role in promoting a zeal for violence. ${ }^{38}$ It is understandable that not all religious leaders will join Archbishop Desmond Tutu and Imam Muhsin Hendricks in fighting bigotry. It needs to be emphasised, nonetheless, that it is incumbent upon all religious leaders to condemn and prevent violence against sexual and gender minorities even if they believed non-heterosexual and non-heteronormative individuals to be sinful.

\section{Piece by piece: The African Commission as a potential but problematic forum}

While the African Union (AU) and its human rights organs ${ }^{39}$ are good starting points for dialogue about LGBT rights, the conversation needs to be carried out primarily in African nations themselves. Care needs to be taken in choosing a legal strategy at the regional level because, if the African Commission is forced to make a decision now, it may end up with a decision that legitimises the violation of LGBT rights. As noted earlier, there is a move by and in African nations to Africanise Western homophobia that is particularly incensed by the successes of protecting LGBT rights in the west. If the African Commission were to hold that LGBT rights are un-African or takes some form of a cultural relativist stance in a binding decision, it effectively will set the clock back on the discourse that has picked up momentum over the last decade.

It is in recognition of this fact that the International Gay and Lesbian Human Rights Commission, for example, warned against bringing gay rights issues to the African Commission. ${ }^{40}$ Two scholars

38 This was exemplified during the Rwandan genocide where the churches did not oppose the genocide or sometimes directly or indirectly supported it. See T Longman Christianity and genocide in Rwanda (2010). While religious leaders have been trying to delegitimise the violence, the role of religion in the actions of the Anti-Balaka and Boko Haram is undeniable.

39 Although there is an African Court on Human and Peoples' Rights, only seven states have made a declaration allowing individuals or NGOs to apply to it. This means that, as far as the rest of Africa is concerned, it is only the African Commission that has the power to forward cases to the Court and the Commission has so far been quite reluctant to do so. It is for this reason that it is the Commission and not the Court that is discussed in this article. Generally, see AM Ibrahim 'Evaluating a decade of the AU's protection of human rights and democracy: A post-Tahrir assessment' (2012) 12 African Human Rights Law Journal 46-47.

40 International Gay and Lesbian Human Rights Commission 'Making the mountain move: An activists guide to how international human rights mechanisms can work for you' http://www.iglhrc.org/sites/default/files/186-1.pdf (accessed 30 July 2015). 
who may be regarded among the most prominent experts on African human rights law, Rachel Murray and Frans Viljoen, hold the same position. ${ }^{41}$ Two trends in the Commission's work affirm that this conclusion is still valid.

First, the African Commission's 2010 refusal to grant the Coalition of African Lesbians (CAL) observer status, a status that is normally easy to attain, indicates that the Commission can be extremely reluctant to make a controversial but forward-looking decision on LGBT rights. The Commission justified its decision, a decision which at the time had been pending for two years, by noting that the activities of CAL did not promote any of the rights enshrined in the African Charter on Human and Peoples' Rights (African Charter). ${ }^{42}$ Although the Commission granted CAL observer status subsequently, in April 2015, the decision followed a concerted seven-year campaign by CAL, joined by many major human rights organisations in Africa, and a significant amount of resistance from the Commission.

Institutional resistance to LGBT rights is amplified by the fact that some commissioners exhibit ignorance about LGBT issues or even show signs of homophobia. In the Commission's published reports on prisoners' rights, one sees an obsessive concern over homosexuality, independent of concerns over health or sexual abuse in prisons. ${ }^{43}$ One report, for instance, identifies primarily male 'homosexual relations' as a separate 'area of concern', while rape and sexual assault are not directly mentioned in the document. ${ }^{44}$ In the same report, the Rapporteur writes:

Homosexuality does not seem to be as widespread or receive the same favourable conditions for its existence in all the prisons. The causes that promote this phenomenon range from non-fulfilment by the prison authorities of certain vital needs of the prisoners (food, toiletries, blankets ...) to overcrowding, which is reaching alarming proportions in some prisons and other places of detention. The risk is specially high when

41 R Murray \& F Viljoen 'Towards non-discrimination on the basis of sexual orientation: The normative basis and procedural possibilities before the African Commission on Human and Peoples' Rights and the African Union' (2007) 29 Human Rights Quarterly 86106 (pointing to the homophobia expressed by individual commissioners and the fact that the commissioners were going to defer to the interests of the governments that appointed them. They warn that bringing cases to the Commission at this point will hurt LGBT rights by setting legal precedents that will take a long time to reverse.)

42 Report of the African Commission on Human and Peoples' Rights (ACHPR) EX.CL/ 600(XVII) para 33 19-23 July 2010).

43 See Dr Vera Mlangazuwa Chirwa, Special Rapporteur on Prisons and Conditions of Detention, Prisons in Malawi: Report on a Visit 17 to 28 June 2001 (Series IV No 9); Dr Vera Mlangazuwa Chirwa Special Rapporteur on Prisons and Conditions of Detention, Prisons in Mozambique: Report on a Visit 4-14 April 2001 (Series IV No 8). (While these reports do connect homosexual acts and relationships in connection with health concerns and sexual abuse, one nonetheless senses an independent concern over male homosexuality.)

44 Special Rapporteur on Prisons and Conditions of Detention, Prisons in Namibia: Report to the Government of Namibia on the Visit of the Special Rapporteur on Prisons and Conditions of Detention in Africa from 17 to 28 September 2001

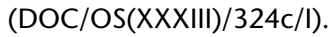


adult prisoners are housed together with minors ... A prisoner who spent more than five months in prison went to the clinic for a consultation about a perianal gonorrhoeal abscess that could only have been caused by homosexual relations.

Even when indirectly discussing rape and sexual abuse of young prisoners, the commissioner seems to see the problem primarily as one of homosexuality rather than sexual and physical abuse. There may, one would suspect, be advocates of non-recognition of LGBT rights within the African Commission independent of political/ pragmatic considerations of the Commission as an institution.

The second reason that makes the African Commission's protective mandate, or its complaint mechanism, an unattractive forum for the time being is that it is likely to show great deference to the currentlyprevailing position of African political elites on LGBT rights. This will continue to be the case, especially if the 'LGBT rights are un-African' narrative is taken up by states as an anti-neocolonial stance. In the latter case, the situation of LGBT rights will deteriorate as not only will official persecution intensify in domestic systems, but the AU can be mobilised to shield member states from condemnation as an expression of African solidarity. ${ }^{45}$

Going back to the CAL example, in addition to the commissioners' views on LGBT rights, the initial rejection in 2010 was probably influenced by the threat of state delegates to withdraw from the regional system or even to bring a communication against South Africa because it guarantees LGBT rights in its Constitution. ${ }^{46}$ Even after the Commission decided in 2015 to grant CAL observer status, the AU's Executive Council, which is composed of Ministers from all member states, asked the Commission to withdraw the observer status of CAL, which it accused of trying to 'impose values contrary to the African values'. ${ }^{47}$ In a bid to prevent similar decisions in the future, the Executive Council went further by asking the Commission to reconsider the criteria it uses to grant observer status and to bring these in line with 'fundamental African values, identity and good traditions'. ${ }^{48}$

Considering how the African Commission and AU member states are reacting to something as trivial as the granting of observer status to one NGO, one could imagine that the political organs will be disposed to take more drastic measures to prevent the development of far-reaching precedents. With enough pressure from the AU's political organs, on a matter they are increasingly tagging as a pan-

$45 \mathrm{Eg}$, this has been the case in relation to the International Criminal Court's work on Africa. See Ibrahim (n 39 above) 48 57-61.

46 For a detailed discussion of the decision and the circumstances surrounding it, see $S$ Ndashe 'Seeking the protection of LGBTI rights at the African Commission on Human and Peoples' Rights' (2011) 15 Feminist Africa 27.

47 AU Executive Council, Decision on the 38th Activity Report of the African Commission on Human and Peoples' Rights Doc.EX.CL/921 (XXVII) para 7. As above. 
African issue and one that has populist appeal, there is a great possibility that the Commission can be pressured into making a substantive decision contrary to the interests of LGBT rights. Compared to the first CAL decision, a precedent-setting adverse decision by the Commission would be much more difficult to reverse and would take much longer to undo as well. One also has to bear in mind that many African leaders who face democracy/legitimacy deficits may find in this matter an opportunity to rally their constituencies behind them and to garner whatever fleeting legitimacy they can muster out of this situation. Therefore, the political organs of the $\mathrm{AU}$ are almost guaranteed to put concerted pressure on this issue, including through the process of the appointment of commissioners.

For these reasons, before any significant push is made in legal litigation, there needs to be a discourse on LGBT rights that requires development from the ground up. Since most international human rights bodies ${ }^{49}$ already recognise LGBT rights as part of their nondiscrimination and privacy regimes, international law can be an important discursive tool. In areas where decriminalisation is not possible, activists should focus on the rights of LGBT individuals to work, associate, express their views and be free from violence and discrimination. Such a non-confrontational approach will give LGBT individuals and activists some breathing space to pursue pro-rights discourses and is feasible since the claims to protection would be based on pre-existing laws and jurisprudence.

This approach has been successfully deployed in Kenya and Botswana, where local LGBT rights non-governmental organisations (NGOs) achieved legal recognition after suing their respective governments for denying them legal registration. In the Kenyan High Court case, Eric Gitari v Non-Governmental Organisations Co-ordination Board \& 4 Others, the Court decided the case based on an extensive review of international and regional law on the freedom of association. ${ }^{50}$ In addition to relying on international treaties, the Court held that the jurisprudence of the African Commission, the African Court on Human and Peoples' Rights and the UN Human Rights Council on the freedom of association led to the conclusion that the prohibition of homosexual acts did not preclude LGBT individuals from freely associating. The Court also relied on case law from Botswana, South Africa, Uganda, the United Kingdom and the

49 These include the UN Human Rights Committee; the UN Committee on Economic, Social and Cultural Rights; the UN Committee on the Elimination of Discrimination against Women; the UN Committee on Torture; the UN Committee on the Rights of the Child; and the UN High Commissioner for Human Rights. The African Commission's decision in Zimbabwe Human Rights NGO Forum $v$ Zimbabwe (2006) AHRLR 128 (ACHPR 2006) falls in this category as it can be used as a discursive tool in as long as the Commission is not given opportunities to explicitly reverse the implications of the pro-LGBT rights statements in that decision.

50 Petition 440 of 2013. 
United States to support its conclusion. Although the Court does not emphasise the point or elaborate it in any detail, it unequivocally recognises LGBT groups as 'a minority and vulnerable group'.

It is when or in places where a certain level of acceptance of LGBT rights has been achieved that a significant push towards decriminalisation should be attempted. A ground-up approach ought to begin a decriminalisation campaign from the state level as it is only with the erosion of criminalisation of non-heterosexual sexuality in member states that the African Commission will be ready to deal with major LGBT rights issues. However, wherever there is a chance that a push for decriminalisation can lead to more criminalisation, activism should harken back to public discourse which cannot be used to stir moral panic by homophobic campaigners.

\section{Moulding regional dialogue and the performative role of soft law}

Murray and Viljoen suggest different interim techniques of lobbying the African Commission, including by the adoption of resolutions, the establishment of specialised mechanisms, and granting LGBT organisations observer status with the Commission. ${ }^{5 T}$ One may also add that, even if the commissioners would not at this time go as far as supporting decriminalisation, it is probable that they would not uphold laws that allow discrimination based on sexual orientation or gender identity or laws that provide for content-based prohibition of expression. For example, the Commission's Special Rapporteur on Human Rights Defenders has strongly criticised new antihomosexuality legislation in Nigeria and Uganda for proscribing the promotion of LGBT rights. ${ }^{52}$ The Working Group on Death Penalty and Extra-Judicial, Summary or Arbitrary Killings has also expressed concerns over the continent-wide increase in proposed amendments to impose the death penalty on homosexuality, an act which does not meet the threshold of 'most serious crimes' which justify capital punishment. ${ }^{53}$

Commissioners also seem to recognise the human rights implications of laws and practices that proscribe or discriminate against LGBT individuals in the provision of health care and the provision of HIV/AIDS treatment or management. For example, the African Commission raised concerns regarding discrimination in the

51 Murray \& Viljoen (n 41 above) 107-108.

52 African Commission on Human and Peoples' Rights, Press release on the implications of the Same-Sex Marriage (Prohibition) Act 2013 on human rights defenders in Nigeria, 6 February 2014; African Commission on Human and Peoples' Rights, Press release on the implications of the Anti-Homosexuality Act on the work of human rights defenders in the Republic of Uganda, 11 March 2014.

53 Commissioner Kayitesi Zainabo Sylvie, Intersession Activity Report 28 April-12 May 2014. 
provision of medical treatment in its reports on the rights of persons living with HIV/AIDS, ${ }^{54}$ and one report also notes that criminalisation is a hindrance to the provision of medical treatment. ${ }^{55} \mathrm{~A}$ backhand reference to the Commission's acceptance of non-discrimination is also recognised, again with reference to HIV and AIDS, in General Comments on articles 14(1)(d) and (e) of the Protocol to the African Charter on Human and Peoples' Rights on the Rights of Women in Africa. The Commission raised concerns over human rights issues connected with homosexuality in its country visits and subsequent reports regarding Cameroon, Namibia and Uganda. This means that, despite the risks associated with the Commission, it holds out some promise in protecting LGBT rights and these same openings can introduce the LGBT rights discourse to the institution.

By far the strongest and most exhaustive pro-LGBT rights decision of the African Commission came from its Resolution on Protection against Violence and Other Human Rights Violations against Persons on the Basis of their Real or Imputed Sexual Orientation or Gender Identity. ${ }^{56}$ Although this Resolution addresses the right to be free from discrimination, the right to life and the right to be free from torture and similar forms of treatment/punishment, it does not at first sight seem to afford any more protection than the pro-rights resolutions that preceded it. However, its preambular mention of the African Charter's articles 2 (non-discrimination) and 3 (equal protection of the law) sets up a conceptual paradigm based on which protection can be broadened from discrimination in healthcare and HIV and AIDS treatment to discrimination in public or private sector employment, housing, social services, and so on.

Despite the fact that this Resolution is by far the most progressive document to come from the African Commission, it is clear that the Commission is very careful in how it deploys it. Except for its recognition of LGBT rights as legitimate human rights (or minority rights) concerns, the substantive part of the Resolution contains issues that are already protected by regional and domestic law. One will also

54 Commissioner Reine Alapini Gansou, Intersession Report to be presented to the 59th session of the African Commission on Human and Peoples' Rights, April 2011-October 2011.

55 Commissioner Lucy Asuagbor, Activity Report presented to the special 52nd ordinary session of the African Commission on Human and Peoples' Rights, in commemoration of the 25th anniversary of the Commission, 9-22 October 2012.

56 African Commission on Human and Peoples' Rights Resolution 275, meeting at its 55th ordinary session held in Luanda, Angola, from 28 April to 12 May 2014. One could argue, as was implied by Rudman (A Rudman 'The protection against discrimination based on sexual orientation under the African human rights system' (2015) 15 African Human Rights Law Journal 1-27), that the African Commission has, in Zimbabwe Human Rights NGO Forum v Zimbabwe (n 49 above) para 169, already accepted the legal standard in which arts 2 and 3 are presumed to incorporate discrimination based on sexual orientation. While this point may be raised in the pro-rights discourse and even in domestic litigation, it should not be taken as a signal of the Commission's preparedness to take more progressive steps. 
note that the Resolution is extremely carefully worded to avoid the issue of decriminalisation. The Commission's Resolution, therefore, carefully but slowly entrenches what it had already achieved rather than blazing a trail. It is partly because of this attitude of the Commission that LGBT rights activism should be built from domestic jurisdictions, which will make it easy for the Commission to slowly build a jurisprudence of non-discrimination and eventually build up to decriminalisation.

An additional way in which momentum for LGBT rights protection can be incrementally built from the ground up is the lobbying of subregional organisations. Since many sub-regional economic communities in Africa either contain specific reference to human rights or indirectly deal with human rights issues, mainstreaming human rights and LGBT rights concerns in their work might be possible. ${ }^{57}$ Such an approach was taken by the Human Rights Awareness and Promotion Forum, a Ugandan NGO, which brought a case against Uganda at the East African Court of Justice. Although it is not clear whether this - still pending - case will be discontinued because Uganda's Anti-Homosexuality Act has been overturned, the application's aggressive or litigation approach creates the risk of creating hard-to-reverse precedents.

Where sub-regional organisations' specific projects and declarations inculcate issues of equality, such actions may be used later to prove growing consensus or even opinio juris when the issue is finally litigated at the African Commission. The best example for this is probably including a prohibition of discrimination based on sexual orientation and gender identity in the different protocols, declarations and procedures that relate to regional and sub-regional HIV/AIDS policies and projects or those relating to aid distribution. If there is any role Western donors can play without feeding the neo-colonialism narrative, it should be as sponsors of these projects. Because the work of these sub-regional organisations usually is outside the public view, African leaders are unlikely to make them grounds for proving their homophobic credentials. These institutions can provide fora where non-threatening reforms that can improve the conditions of LGBT communities and also promote respect for general rights.

South Africa, a country that has played such a pivotal role as the constitutional model in Africa, already is playing a diffusional role both at the African and international level with regard to LGBT rights. Rather than focusing on the African Commission, it is better to get to the Commission from the ground-up. It is important that South Africa replaces the west as a point of diffusion as its tortured history of fighting antiquated imperial values will give it legitimacy in pressuring fellow African nations. While the same could be said of African countries such as Cape Verde and Mozambique, those that specifically

57 See OC Ruppel 'Regional economic communities and human rights in East and Southern Africa' in A Bosl \& J Diescho (eds) Human rights in Africa (2009) 275. 
ban discrimination based on sexual orientation or gender identity without going as far as recognising same-sex marriage, can also take a leading role among their political peers.

One of the ways in which countries like South Africa can take on this role, for example, is in the role it plays in its immediate region and in the AU. The Southern African Development Community (SADC) can be used to diffuse the South African legal discourse. Although the SADC's tribunal has for the time being been shut down at the insistence of Zimbabwe, ${ }^{58}$ the SADC human rights treaty can still be used to promote LGBT rights. For example, a conflict of laws or specifically recognition of foreign marriages regime can be used to challenge the homophobic laws of neighbouring states. ${ }^{59}$ Among the objectives of SADC is the harmonisation of political and socioeconomic policies of member states. ${ }^{60}$ This would allow South African law, the law of the largest economic player in the region, to either get recognition to South African marriages or even be used as a model for legal reform.

Looking to South Africa as a source of pro-LGBT rights influence is, however, not unproblematic. South Africa's regional hegemonic ambition may overshadow the importance of human rights in its foreign policy. The latest example of this conflict manifested itself when the South African government allowed Omar al-Bashir to slip out of the country despite a High Court decision barring him from doing so. In addition to its cordial relations with the worst offenders in Africa, South Africa has also been criticised for sending lower level officials to African Commission sessions, signalling the minimal importance it accords to the institution and its processes. ${ }^{61}$ The government's dilemma on human rights as a foreign policy item is understandable as it would not be able to as easily work, trade and mingle with a large number of African governments if it were to be adversarial about their human rights records. Despite the difficult position in which the South African government finds itself, it has to be recognised that, given that Western pressure on LGBT issues is unwelcome, South Africa is the only best alternative as a leading state actor. Therefore, LGBT rights advocates are well advised not to take South Africa's role for granted and to promote South African leadership, not only in LGBT rights but in human rights in general.

58 C Gilbert \& K Beck 'Killing Southern Africa's Human Rights Court' Freedom House 29 August 2012.

59 Even if non-state actors are not given standing, the tribunal would probably still be able to hear cases brought by the South African government that would espouse the interests of its LGBT citizens who get married in South Africa, but are doing business in other SADC nations.

60 Art 5 of the Treaty of the Southern African Development Community, Windhoek (as amended) 1992/1993, in (1993) 5 African Journal of International and Comparative Law 418.

61 Coalition of African Lesbians, African Commission http://www.cal.org.za/new/ ?page_id=49 (accessed 30 July 2015). 
While South African soft power ought to be utilised as much as feasible, the deployment of European or American influence should be avoided and used with extreme care when unavoidable. It may be advisable for LGBT rights advocates to make good use of American and European (governmental and non-governmental) influence to encourage discourse on LGBT issues. The use of Western hegemony to do more than that will result in an unnecessary backlash. For example, a push for civil equality in a state where homosexual acts are not criminalised potentially can result in criminalisation, or the condition may change from criminalisation to more severe punishments as it had in Uganda, The Gambia and Nigeria, ${ }^{62}$ where anti-LGBT groups are able to galvanise anti-imperial sentiments. Additionally, the deployment of Western hegemonic power will not only reinforce the narrative that LGBT rights are a neo-colonial agenda, but will put African human rights defenders in an extremely difficult position where they would have to fight homophobia in their countries while at the same time struggling against the appearance that they are on the side of a neo-colonial agenda even if they were in reality panAfricanists.

\section{Conclusions}

As the evangelical movement galvanises moral outrage and gathers momentum, it is becoming clear that sexual and gender minorities will face a great deal of persecution. As one Ethiopian pastor suggested, if these movements are successful, 'Africa will become a graveyard for homosexuality'. ${ }^{63}$ This promise had already come to full fruition in Uganda for some time and in The Gambia and Nigeria, where harsh laws were tightened. In both countries, mob violence has been unleashed against minorities and advocates of their rights. Most of the homophobic discourse may be morally deplorable and substantively laughable to the point that it is difficult to believe its success. However, the net effect of the homophobic lobby and the overlap with the interest of undemocratic regimes grappling for fleeting moments of public acknowledgment may result in the practical Africanisation of homophobia.

A positivistic analysis of the current state of international human rights law will no doubt lead to the conclusion that LGBT rights are recognised as a part of the principle of non-discrimination and that of privacy. However, this conclusion is not to be taken for granted as there is a real possibility that a new norm or norms could develop, making an 'African' exception to LGBT rights. Rather than bringing

62 See S Katyal 'Exporting identity' (2002) 14 Yale Journal of Law and Feminism 99100.

63 KJM Baker 'A graveyard for homosexuals' Newsweek 12 December 2013 (quoting Seyoum Antonius, an Ethiopian evangelical leader and president of United for Life, a homophobic, anti-condom and anti-abortion organisation). 
international law to court, where it risks being reinterpreted fundamentally and frozen in a homophobic moment, it should be kept in the agora just outside the gates of courts where it can influence and challenge public opinion. It is only after international law is used as a basis of public discourse that judicial discourse should be attempted.

LGBT rights advocacy should initially aim at disrupting the homosexuality as 'un-African' narrative, thereby averting a statesponsored pan-African homophobic front. At this stage, the most important role of international law should be the prevention of the promulgation of laws that impose greater penalties on LGBT acts and identities at the domestic level. International legal standards should also be included in non-binding soft law pronouncements where they can have a performative role. Subsequently, and in some situations simultaneously, work should be done to decriminalise homosexuality in African states. If enough African states move towards decriminalisation at the domestic level, international law may be considered as a point of departure for litigation at the constitutional and regional levels.

While activists work to ward off the shores of Africa a neo-colonial religious zealot movement that is seeking a battle ground to avenge its recent losses in the west, they need to be careful about repeating the mistakes of the homophobia campaign. While it may be tempting to deploy the same weapons that vanquished the fundamentalists in the west, they risk westernising yet another element of African sexualities, cultures and identities. Not only are the cultural manifestations of non-heterosexual or non-heteronormative identity not necessarily the same in African societies, but the different linguistic, cultural and symbolic expressions of LGBT rights do not have to necessarily be modelled on what exists in the west. The Western LGBT rights discourse came to be as an interaction of local agents reacting to specific contexts and those contexts may or may not exist in Africa. Indigenous LGBT discourses, organisations, activists and religious leaders should, therefore, take the lead in LGBT rights promotion in Africa. 